\title{
Six Strings of Student Groupings: Applying Sunzi to the Language Classroom
}

\author{
Jason D. Hendryx \\ National Taiwan Normal University
}

\begin{abstract}
A teacher approach for grouping students in the language classroom derived from Sunzi's Art of War and guided by almost a decade of classroom observations is introduced here and then explained. The six types of student groupings identified in this approach are 1) individual, 2) pairs, 3) small groups, 4) half the class, 5) the entire class, and 6) combinations and transformations of these first five groupings. For each student grouping string suggested, a brief pedagogical rationale supporting its use is offered, several examples of how it might be employed in the classroom are provided, and teacher and student points for reflection are suggested. By presenting an approach to student groupings, it is hoped that language teachers will be intrigued by the opportunities such groupings can offer and be reminded that their classrooms are places of language learning with nearly limitless grouping and interactional possibilities.
\end{abstract}

Sunzi is the reported author of the Art of War, an ancient Chinese military text written over two thousand years ago. In recent decades, Sunzi's work has been employed successfully in business applications. As education incorporates more business models, it may prove advantageous for the text to be mined for educational possibilities as well. Applying Sunzi to the educational endeavor is not so outlandish if Sunzi's struggle for success on the battlefield is re-envisioned as a struggle for success in the classroom. In the fifth chapter of the extant version of the Art of War, the title of which is often translated as "potential force," a passage with possible educational applications can be identified:

Musical notes are but five, transform these five notes, and one could not hear them all. Colors are but five, transform these five colors, and one could not see them all. Flavors are but five, transform these five flavors, and one could not try them all. (Translation by author)

By taking these five notes, colors, and flavors, and envisioning them as student grouping strings, a potentially powerful grouping model emerges. Indeed, Harmer (2001) remarked, "There is no real limit to the way in which teachers can group students in a classroom" (p. 114). This approach then is intended to describe one possible orientation for teachers to consider when grouping students in language classrooms for efficient, effective, and hopefully enjoyable classroom interaction. The approach is not intended to be either prescriptive or bound to any one language teaching method. At its heart is an attempt at addressing Van Lier's (1988) claim that "we have failed to consider the communicative potential of the classroom itself" (p. 30).

Language Education in Asia, 2012, 3(2), 176-183. http://dx.doi.org/10.5746/LEiA/12/V3/I2/A06/Hendryx 
In the language classroom, language learners not only learn, but hopefully also use and create language for their immediate linguistic classroom realities as well as train for their possible linguistic futures. Therefore, "exploiting this potential for learning involves exploring the meaning which the classroom has for students and the communicative dynamics which it can generate" (Tudor, 2001, p. 115).

Language teachers can certainly further enhance both the kinds and modes of classroom interaction which are currently being employed (Rivers, 1987; Walsh, 2011). One way to enhance current interactional patterns and further engage the communicative as well as the interactional potential of the classroom would be to embrace a systematic and informed approach toward grouping students. Many language teachers are familiar with using a variety of student grouping approaches in their classes. Bassano and Christison (1987) offer six categories of groupings which are 1) restructuring, getting up and moving around, 2) onecentered, focusing on one individual, 3) unified group, all group members participate in the task, 4) dyads, in which a student talks with another student about feelings and emotions, 5) small group, and 6) large group. Scrivener (1994), meanwhile, suggests five common grouping formats, "the whole class working together with the teacher, the whole class mixing together as individuals; small groups (three to eight people); pairs; [and] individual work" (p. 13). These grouping categories and formats provide a basis from which the six string approach can now be viewed.

\section{The First String: Individual}

The individual string is when a teacher talks to a student individually while the rest of the class listens in. This exchange could come in the form of a warm-up activity, practicing a new question pattern, comprehension check query, or just chatting. It is through this type of interaction that language teachers can learn a great deal about their students and the language abilities they possess (Brown, 2001). This is one of the most direct ways teachers can discover who their students are as individuals. At the core of this type of interaction is the InitiationResponse-Feedback (IRF) framework. It is in this type of grouping where a number of language instructors spend a great deal of their time, perhaps too much of their time.

While individual grouping is essential in terms of developing teacher-student rapport, such exchanges during class must be crisp, quick, precise, and meaningful. Too often language instructors, both novice and experienced, have been observed in classrooms getting bogged down in individual student interactions. As a result, the class often loses pace and students not directly involved in the interaction appear to lose focus.

Language teachers have often remarked that they believe when individual exchanges are taking place, there is some kind of peripheral learning occurring in other learners. One suggestion for teachers when engaged in individual interactions is to keep the exchanges moving and involve others in these interactions as much and as soon as possible. Another possibility would be to develop a worksheet or note card to be used by non-participating students to record some feature or features of the conversations they are hearing. Such preparation would move expected peripheral participation and learning to ensured peripheral learning of a type and kind the language teacher has determined to be of most benefit.

Some points of reflection for teachers in individual interactions are, "Have both old and new vocabulary and grammatical patterns been used?" "How should corrections be provided if they are needed?" "Were student views and opinions respected?" Students directly and indirectly involved in individual interactions could reflect on how much of the interaction they felt they 
understood. "Which parts did they have trouble with and why?" If they spoke, did they feel comfortable doing so in front of the class and if not, why?

\section{The Second String: Pairs}

Two students speaking together about a particular topic, pattern, or question for practice and production is considered pair work. Pair work is the most commonly employed cooperative learning student grouping (Brandl, 2008). It is often utilized in the language classroom for reasons of quantity of language production, control, ease of use, visibility, focus, reduced anxiety, and accessible task variety (see Brown, 2001; Harmer, 2001; Lewis \& Hill, 2002).

A straightforward grouping for students to practice and produce language on their own without having to wait on instructor contributions is to have them form pairs. With pairs, teachers can easily see who is or is not engaged and have some measure of control over the situation. In addition, the language being used in pair work can be highly focused, students do not have the additional pressure of speaking in front of the entire class or in a larger group, and a great number of language tasks can be readily employed in pair-work interactions (e.g., information gap, question / answer).

Oftentimes, however, instructors do not properly model pair-work processes and expectations (Lewis \& Hill, 2002). The result is that students often spend several minutes attempting to determine precisely what it is they are supposed to do in pair work. While some pair work in language classes ends abruptly and another segment of the lesson is introduced, often an instructor selects one or two pairs to go over what they have done to serve as a kind of comprehension check and activity closure.

Teachers having students engage in pair work may want to consider the following questions: "Is the pair work properly explained and modeled?" "Are students prepared to engage the language at the level expected?" "How will the effectiveness of the pair work be assessed?" "How will the pair work be concluded?" Students involved in pair work might ask themselves, "Do I know what I am supposed to do?" "How can I use the language I know, both new and familiar, in this pair work?" (see Brandl, 2008; Shrum \& Glisan, 2005).

\section{The Third String: Small Groups}

Three to six (or more, depending on class size) students working together are considered a small group. Group work in the language classroom was, and in some cases still is, seen as a largely unknown, untried, and unproven approach for students to learn a language. However, this kind of thinking about small groups is changing. "There is now considerable evidence that the interactions that take place during group work facilitate language acquisition" (Ellis, 2008, p. 818). Ellis also remarks that small group learning can increase 1) the quantity of learner speech, 2) speech acts, 3) motivation, 4) individualized instruction, 5) enjoyment, 6) independence, 7) social integration, 8) knowledge concerning how to work with others, and 9) learning; it also reduces anxiety (see Ellis, 2008, p. 814). Small groups are also good for skits, jigsaw tasks, and various production and / or review activities.

However, as with pair work, the importance of proper modeling for group work to be effective must be stressed, as should be the need for some kind of student product to be created and utilized for students to develop a positive association toward group-work processes. For example, the language, opinions, and beliefs created by students in group work can be reintegrated back into curriculum by teachers throughout a course. After all, group work involves more than just putting students together and giving them something to do; it entails 
detailed planning and a clear understanding of the goals and outcomes the group work is aimed at achieving (Jacobs \& Hall, 2002).

Language instructors employing group work might consider "How is the group work structured to maximize involvement, interest, understanding, and interaction?" "How will group work be integrated back into the larger lesson?" "What small-group language products are being sought?" "Have students been properly prepared to be able to create such language products?" "Have student group-work roles and expectations been adequately explained?" Teachers should be cognizant of the complexities involved in developing and presenting interactional opportunities for students. Kang (2002) captures many levels of this complexity by identifying that teachers need to "tailor their instruction carefully to the needs of learners and teach them how to listen to others, how to talk with others, and how to negotiate meaning in a shared context" (p. 208).

Students engaged in group work could think about how they will take an active part in the group, what they should take responsibility for in group work, and how they should interact with their group partners.

\section{The Fourth String: Half the Class}

Half the class grouping is created when the teacher divides the class into two equal or nearly equal groups. Half of the class is asked to develop a particular stance toward a topic, statement, or question, while the other half of the class is asked to develop the exact opposite stance (i.e., Yes / No; For / Against). Each group then defends its stance against the other group in the form of a debate. Such groupings can serve as head-to-head competitions to either introduce or conclude a topic of study. Furthermore, if topics are debated in playful ways, such groupings could further enhance classroom dynamics and aid in the retention of the language being taught by making it more memorable and situating it within a specific context.

Half-class groupings promote a low-stress environment and foster the potential for different modes and types of classroom interaction, allowing for the possibility of more spontaneous language to be produced. These groupings also provide for more complex tasks to be attempted as the number of students working together is increased, while the number of groups teachers must monitor is reduced to just two (Jacobs \& Hall, 2002). Such groupings also have the potential to engage several of the factors identified by Dörnyei (2001) as important in developing cohesive groups, such as students learning about each other, cooperating within their groups, and entering intragroup competitions.

Teachers could consider if the topic chosen for half-class student grouping is appropriate, how student-generated concepts and ideas in this type of grouping could be further utilized and expanded, and how student interactions and language production in such a grouping might be monitored and assessed. Students in half-class groupings might consider how, when, and what they can contribute.

\section{The Fifth String: The Entire Class}

In entire-class groupings, all students participate simultaneously and questions are directed by the teacher to the class as a whole and not at any one individual. In this grouping, teachers can give instructions, provide introductions, offer learning models, seek student input, furnish topics for study and review, and supply summaries and conclusions. This grouping format "reinforces a sense of belonging" among classmates while providing teachers with "a general understanding of student progress" (Harmer, 2001, p. 114). Commands for the entire class to 
carry out could also be given while in this grouping, which would access the common-threat factor mentioned by Dörnyei (2001), which builds solidarity among "fellow-suffers" in the language classroom (p. 44).

Teachers using this grouping might consider, "How can the entire class be engaged?" "What are the goals of this grouping?" Students could ask themselves, "What is being presented?" "How am I being involved in this grouping?" "What can I contribute?"

\section{The Sixth String: Combinations of the First Five Groupings}

In the sixth string, the first five student groupings are combined and transformed to provide potentially limitless combinations of student grouping possibilities (Harmer, 2001). Five combined student grouping possibilities presented here are 1) individual and small groups, 2) individual and the entire class, 3) pair work and the entire class, 4) small group and the entire class, and 5) half the class and the entire class.

A combination of individual and small groups might involve individuals temporarily separating from their original groups to share and or learn something from other groups, later returning to their original groups to report what they have learned (i.e., a form of jigsaw). Individuals in an entire-class interaction are often seen in a mingling activity, where individuals interact with all their classmates, oftentimes to gather specific information from them (e.g., age, number of siblings, hobbies).

Pairs applied in an entire-class grouping might involve splitting the class in half, giving each half a different orientation to a particular topic, and then having students pair up and discuss the topic, making sure pairs are composed of students who were given differing views (i.e., information gap). The entire class could be surveyed to determine which of the views was most supported by students. Pairs in an entire class grouping may also come in the form of an innerouter circle grouping, where the outer-circle student asks the corresponding inner-circle student a question or series of questions. The inner-circle student answers the questions and then asks these same questions of the outer-circle student. After the questions have been asked and answered by both inner- and outer-circle students, the entire outer circle rotates one student to the left or right and begins the question and answer process again (Brandl, 2008). When students have asked and answered these questions several times, the entire class could provide feedback on these questions and how they might edit them to make the questions more appropriate for different audiences (e.g., employers, friends, family).

Using small groups and the entire class could involve an expert panel or group of judges who provide advice, feedback, or instructions about a particular topic for the rest of the class. Lastly, a half-class to entire-class grouping could involve each half of the class being given different descriptive features about two distinct places, persons, or actions. Half-class groupings must determine what their features combine to mean and also what the features of the other half of the class combine to mean. When the two places, persons, or actions have been identified, the whole class tries to determine how these two fit together to form an altogether new understanding meaningful to the class as a whole. From these few suggested combined groupings, it should be apparent that there are a great number of potential student grouping possibilities available to language teachers. 


\section{Discussion}

Are language teachers playing all six student-grouping strings outlined here? From almost a decade of language classroom observations, the answer in most cases is no. Many language teachers use two strings, moving from entire class to pair work and then back again. Some teachers occasionally throw in a group activity and an informal chat with an individual student. However, half-class groupings and other combined groupings mentioned here are not frequently observed.

While "there are so many possible ways of stimulating communicative interaction" (Rivers, 1987, p. 14), it appears that some language teachers do not utilize many types of classroom interaction. Student grouping approaches provide a resource for teachers so that every time they enter the language classroom, they can feel empowered by all of the grouping options available to them. Language teachers should remember that "interaction formats . . . in the classroom should reflect the multiple communicative needs and purposes of the social group engaged in the learning process" (Kramsch, 1987, p. 24). Indeed, language learning has been framed by scholars as largely dependent on "what goes on inside and between the people in the classroom" (Stevick, 1998, p. xii).

That being the case, language teachers should push themselves and their students to interact in as many different ways with as many different pedagogical products in mind as possible. When reflecting on the language situations their students might face, language teachers might consider that their students may not always be in cozy encounters with understanding individuals, but occasionally may be put in positions where they must speak at a meeting or offer comments at a conference.

\section{Conclusion}

By placing learners within a variety of student groupings, language teachers are doing much to prepare them for or at the very least make them aware at some level of the different kinds and types of language environments in which they might find themselves (Scrivener, 1994). "Only by broadening their discourse options in the classroom can learners stop being foreignlanguage consumers and become the active architects of interpersonal and intercultural understanding" (Kramsch, 1987, p. 28).

In addition, employing a variety of student groupings has the potential to help language teachers enhance their own teaching craft, especially if it allows them to develop new understandings and insights. Perhaps eventually the use of such groupings can be one element which contributes to a transformation in their own teaching processes. As Underhill (1989) suggests, "the job of the facilitator is not to decide what the students should learn, but to identify and create the crucial ingredients of the psychological climate that helps to free learners to learn and to grow" (p. 251).

With an informed understanding and approach toward student groupings, language teachers may also be better equipped to identify and create the "space for learning" called for by Walsh (2011) which "refers to the extent to which teachers and learners provide interactional space that is appropriate for ... promoting interactions that are both appropriate to a particular microcontext and to specific pedagogical goals" (p. 166). To conclude, while Sunzi intended his wisdom to be applied to the battlefields of long ago, there is nothing to stop that same knowledge from being employed in today's language classrooms to enhance understandings of student grouping possibilities. 


\section{Author Note}

Jason D. Hendryx, Department of Applied Chinese Language and Literature, National Taiwan Normal University, New Taipei City, Taiwan.

Correspondence concerning this article should be addressed to Jason D. Hendryx, Department of Applied Chinese Language and Literature, National Taiwan Normal University, No. 2, Sec. 1, Ren Ai Road, Lin Kou District, New Taipei City, Taiwan, 24449. Email: jhendryx@gmail.com 


\section{References}

Bassano, S. K., \& Christison, M. A. (1987). Developing successful conversation groups. In M. H. Long \& J. C. Richards (Eds.), Methodology in TESOL: A book of readings (pp. 201-207). Boston, MA: Heinle \& Heinle.

Brandl, K. (2008). Communicative language teaching in action: Putting principles to work. Upper Saddle River, NJ: Pearson.

Brown, H. D. (2001). Teaching by principles: An interactive approach to language pedagogy (2nd ed.). White Plains, NY: Longman.

Dörnyei, Z. (2001). Motivational strategies in the language classroom. Cambridge, England: Cambridge University Press.

Ellis, R. (2008). The study of second language acquisition (2nd ed.). Oxford, England: Oxford University Press.

Harmer, J. (2001). The practice of English language teaching (3rd ed.). Essex, England: Longman.

Jacobs, G. M., \& Hall, S. (2002). Implementing cooperative learning. In J. C. Richards \& W. A. Renandya (Eds.), Methodology in language teaching: An anthology of current practice (pp. 52-58). Cambridge, England: Cambridge University Press.

Kang, S. (2002). Factors to consider: Developing adult EFL students' speaking abilities. In J. C. Richards \& W. A. Renandya (Eds.), Methodology in language teaching: An anthology of current practice (pp. 204-211). Cambridge, England: Cambridge University Press.

Kramsch, C. J. (1987). Interactive discourse in small and large groups. In W. M. Rivers (Ed.), Interactive language teaching (pp. 17-30). Cambridge, England: Cambridge University Press.

Lewis, M., \& Hill, J. (2002). Practical techniques for language teaching. Independence, KY: Cengage Learning.

Rivers, W. M. (1987). Interaction as the key to teaching language for communication. In W. M. Rivers (Ed.), Interactive language teaching (pp. 3-16). Cambridge, England: Cambridge University Press.

Scrivener, J. (1994). Learning teaching: A guidebook for English language teachers. Oxford, England: Macmillan.

Shrum, J. L., \& Glisan, E. W. (2005). Teacher's handbook: Contextualized language instruction (3rd ed.). Boston, MA: Thomson \& Heinle.

Stevick, E. W. (1998). Working with teaching methods: What's at stake? Pacific Grove, CA: Heinle \& Heinle.

Tudor, I. (2001). Dynamics of the language classroom. Cambridge, England: Cambridge University Press.

Underhill, A. (1989). Process in humanistic education. ELT Journal, 43(4), 250-260. http://dx.doi.org/10.1093/elt/43.4.250

Van Lier, L. (1998). The classroom and the language learner. London, England: Longman. Walsh, S. (2011). Exploring classroom discourse: Language in action. London, England: Routledge. 